\title{
扁桃周囲膿瘍様経過を呈した扁桃結石例
}

\author{
木村寛・中川肇・浅井 正嗣 \\ 渡辺 行雄・水越 鉄理・小泉富美朝*
}

\section{A Report of a Case with Tonsillolith Mimicking Peritonsillar Abscess; A Case Report}

\author{
Hiroshi Kimura, Hajime Nakagawa, Masatsugu Asai, \\ Yukio Watanabe, Kanemasa Mizukoshi and Fumitomo Koizumi \\ (Toyama Medical and Pharmaceutical University)
}

\begin{abstract}
Recently we treated a patient with a tonsillolith 8.5 grams in weight which is believed to be the heaviest reported in Japan so far. This 26-year-old male patient visited a hospital complaining of pharyngeal pain with no difficulty in swallowing or trismus. A diagnosis of peritonsillar abscess was made from the local findings. Prior to this episode a stony mass had been expelled from right tonsil spontaneously. Tonsillectomy was indicated for the history chronic angina and recurrent peritonsillar abscess. On the morning of admission the tonsillolith was expelled spontaneously, but tonsillectomy was performed because of chronic angina. The operative findings suggested that the stone had been in the right upper region between the capsule of the tonsil and the superior constrictor muscle. It was yellowish gray and measured $30 \times 26 \times 16 \mathrm{~mm}$. Chemical analysis revealed calcium phoshate. In the world literature there have been about 20 reports of large tonsilloliths. This is the largest reported so far in Japan. Our observations and previous reports suggest that recurrent inflammation of the tonsils and peritonsillar tissues promote the accumulation of inflammatory debris in tonsillar crypts, which then become the organic nidus for stone formation. Salts from the saliva may precipitate to form tonsilloliths that gradually increase in size.
\end{abstract}

Key words: peritonsillar abscess, tonsillolith, bilateral tonsillectomy

はじめに

臨床的意義を有する大きい扁桃結石は比較的 稀である．特に重量においては，山脇ら ${ }^{1)}$ の報 告例が本邦では最大で $8.5 \mathrm{~g}$ である. 今回私達 はこれに匹敵する扁桃周囲膿瘍様の所見，症状 を呈した巨大な扁桃結石の一例を経験したので， 若干の文献的考察を加えて報告する。
症例

症例：26歳，男性.

主訴：咽頭痛.

家族歴：特記すべきととなし.

既往歴：小学校検診時に口蓋扁桃肥大を指摘 されていた。1987年に 2 回の咽頭痛，微熱が出 現したがそのまま放置していた。喠石，腎結石， 
尿路結石，胆石の既往はなかった。

現病歴：1988年12月初句に激しい咽頭痛，38 度台の発熱，燕下痛，摂食障害を訴え近医より 抗生剂，消炎剂の投与を受けた。その際，患者 自身, 鏡を見ながら偶然右扁桃上部の白色の硬 い結石様腫瘤に気付き，患者自身で鑷子でピ一 ナッッ大の結石を除去した。1989年12月11日に 咽頭痛, 微熱が生じたが，摂食障害，開口障害 はなかった。同日に近医を受診したところ右扁 桃周囲膿瘍と診断され, 手術適応とされ, 当科 へ紹介された。

初診時所見：耳・鼻・喉頭に異常所見は認め なかった。咽頭はび慢性に発赤があり，右前口 蓋弓およびその上方は特に強く発赤腫脹し, 半

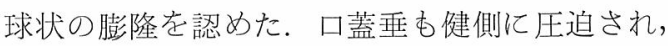
扁桃周囲膿瘍の所見を呈していた。口蓋扁桃は I 度肥大で, 発赤し, 表面は不整で膿栓の付着 は認めなかった。血液生化学的検查では, 白血 球数は, $9700 / \mathrm{mm}^{3}$, CRP 0. $9 \mathrm{mg} / \mathrm{dl}, \mathrm{ASLO}$ 值 $\times 320$ と軽度の上昇がみられた。血清カルシウ ム值, リン值は正常範囲内であった。

臨床経過：1990年 1 月 4 日，当科入院となっ た。同日，拇指頭大の結石の自然排出がみられ た。これにより，自覚症状と所見の急激な改善 がみられた。初彰時認められた右前口圔弓およ びその半球状の膨隆は消失した，右口蓋扁桃上 部の実質は裂け，後口蓋弓に白色渗出様物が付 着していた，扁桃窩上側方に深い窪みがあり同 部位に結石が詰まっていたものと推察された (困 1).X線写真による検索で, 唾石, 胆石,

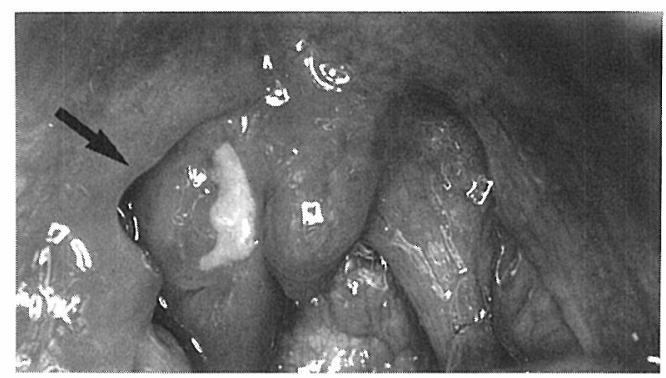

図1 矢印は結石が存在していたと推察される部位. （右扁桃窩上側方）
腎結石は認めなかった。扁桃結石の再発があり， また慢性扁桃炎の所見がみられ，本人屯希望し たため，1990年 1 月 8 日に全身麻酔下で両側口 蓋扁桃摘出術を施行した。手後時, 右口蓋扁桃 実質上部は 2 つに裂け同部位上側方に深い寉み を認めた。右口蓋扁桃剝離時, 扁桃被膜は著し く肥厚し周囲組織との癒着が強く剝離に困難を 要した. 術前に認められた後口蓋弓に付着して いた白色滲出様物は肥厚した被膜であった。 左 口蓋扁桃も同様の所見であった。術中出血は $700 \mathrm{ml}$ であった．術後は経過は良好で，術後 8 日目に退院した。

結石標本：図 2 は自然排出した扁桃結石であ る。結石は, 沜笛状を呈し, 比較的硬く, 表面 は顆粒状であり，大きさは $30 \times 26 \times 16 \mathrm{~mm} ，$ 重 量 $8.5 \mathrm{~g}$ であった。 分析の結果, 成分は燐酸力 ルシウムであった。

組織像：右扁桃摘出の組織像は, 全体的にリ ンパ組織は少なく，扁桃周囲膿瘍の組織像を呈 し，結石に接していた部位は線維性結合織の増 生が著明であった。他の扁桃組織は圧迫されて いたため萎縮していた。残存結石は認められな かった。

\section{考察}

扁桃結石の報告例は外国例を合わせても数少 ない，我々が渉隠し得た報告例21例を参考にし て若干の考察を行なった(表 1 ).

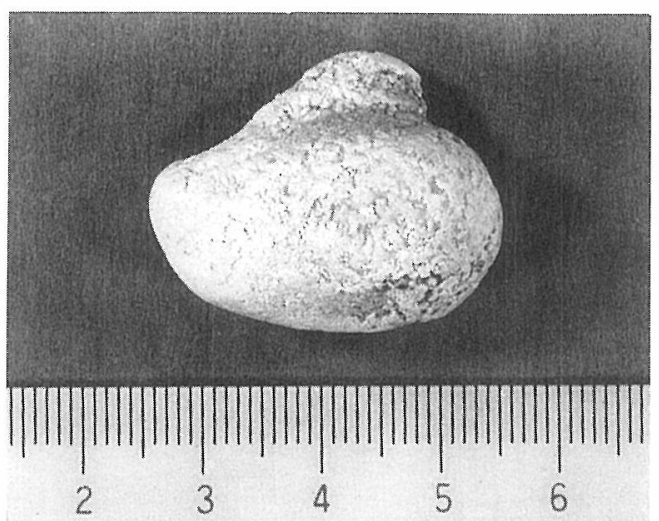

図 2 排出された扁桃結石. 重量 $8.5 \mathrm{~g}$. 
表 1 扁桃結石の報告例

\begin{tabular}{|c|c|c|c|c|c|c|c|}
\hline 報 告 者 & 年粎令 & 性 & 重量 大きさ & 症状・所見 & 初䛦時診断 & 成 & 治 \\
\hline 九谷 & 51歳 & 男 & $\begin{array}{c}2.5 \mathrm{~g} \\
25 \times 12 \mathrm{~mm}\end{array}$ & 鱮 下 痛 & 扁桃周囲膿瘍 & $\begin{array}{l}\text { 燐酸カルシゥム } \\
\text { 有 機 物 }\end{array}$ & 核出術 \\
\hline 堀内 & 19歳 & 女 & $\begin{array}{c}0.65 \mathrm{~g} \\
12 \times 12 \times 12 \mathrm{~mm}\end{array}$ & 咽 頭 痛 & 扁桃周团膿瘍 & $\begin{array}{l}\text { 燐酸カルシウム } \\
\text { 燐酸マグネシウム }\end{array}$ & 核出術 \\
\hline 吉田 & 43 歳 & 男 & $0.5 \mathrm{~g}$ & 曼 下 痛 & 慢性扁桃炎 & & 両側扁桃摘出 \\
\hline 松井 & 22 歳 & 男 & $\begin{array}{c}6.5 \mathrm{~g} \\
24 \times 21 \times 20 \mathrm{~mm}\end{array}$ & 顎 関 節 痛 & $\begin{array}{l}\text { Vincent } \\
\text { Angina }\end{array}$ & $\begin{array}{l}\text { 橉酸カルシウム } \\
\text { 炭酸カルシウム }\end{array}$ & 患側扁桃摘出 \\
\hline 山脇 & 43歳 & 男 & $\begin{array}{c}8.5 \mathrm{~g} \\
65 \times 15 \mathrm{~mm}\end{array}$ & 咽頭狭窄感 & 扁桃 結 石 & $\begin{array}{l}\text { 燐酸カルシウム } \\
\text { 燐酸マグネシウム }\end{array}$ & 患側扁桃摘出 \\
\hline 内藤 & 19歳 & 男 & $\begin{array}{c}6.6 \mathrm{~g} \\
24 \times 22 \times 23 \mathrm{~mm}\end{array}$ & 燕 下 痛 & 扁 桃 結 石 & $\begin{array}{lll}\text { 無 } & \text { 機 } & \text { 燐 } \\
\text { 蛋 } & \text { 白 } & \text { 質 }\end{array}$ & 核出術 \\
\hline 田村 & 41歳 & 男 & $1.1 \mathrm{~g}$ & 咽 頭 痛 & 慢性扁桃炎 & & 核出術 \\
\hline Hiranandani & 65歳 & 女 & $\begin{array}{c}42 \mathrm{~g} \\
25 \times 30 \mathrm{~mm}\end{array}$ & 咽 頭 痛 & 扁 桃 結 石 & $\begin{array}{l}\text { 炭酸カルシウム } \\
\text { 燐酸カルシウム }\end{array}$ & 核出術 \\
\hline Srimali & 63歳 & 女 & $\begin{array}{c}32 \mathrm{~g} \\
25 \times 20 \mathrm{~mm}\end{array}$ & 咽 頭 痛 & 慢性扁桃炎 & $\begin{array}{l}\text { 燐酸カルシウム } \\
\text { 炭酸カルシウム }\end{array}$ & 両側扁桃摘出 \\
\hline Samnant & 45 歳 & 男 & $30 \mathrm{~g}$ & 扁 桃 腫大 & 異所性唾液腺 & $\begin{array}{l}\text { 炭酸カルシウム } \\
\text { 燐酸カルシウム } \\
\text { マグネシウム }\end{array}$ & 核出術 \\
\hline & 16歳 & 男 & $25 \mathrm{~g}$ & 扁 桃腫大 & 扁 桃 結 石 & $\begin{array}{l}\text { 炭酸カルシウム } \\
\text { 燐酸カルシウム } \\
\text { マグネシウム }\end{array}$ & 核出術 \\
\hline $\begin{array}{l}\text { Gapany- } \\
\text { Gapanavicius }\end{array}$ & 26歳 & 男 & $\begin{array}{c}6.7 \mathrm{~g} \\
32 \times 21 \times 17 \mathrm{~mm}\end{array}$ & 咽 頭 痛 & 扁桃周囲膿瘍 & 炭酸カルシウム & $\begin{array}{l}\text { 核出術後, } \\
\text { 両側扁桃摘出 }\end{array}$ \\
\hline Elidan & 25歳 & 女 & $\begin{array}{c}5.2 \mathrm{~g} \\
25 \times 18 \times 15 \mathrm{~mm}\end{array}$ & 扁 桃 腫大 & 扁桃悪性腫瘍 & $\begin{array}{l}\text { 燐酸カルシウム } \\
\text { 蛋 白 質 }\end{array}$ & 核出術 \\
\hline 藤原 & 34歳 & 男 & $\begin{array}{c}5.2 \mathrm{~g} \\
16 \times 17 \times 21 \mathrm{~mm}\end{array}$ & 扁桃白色化 & 扁 桃 結 石 & $\begin{array}{l}\text { 燐酸カルシウム } \\
\text { 蛋 白質 }\end{array}$ & 患側扁桃摘出 \\
\hline Padmanabhan & 40歳 & 男 & $\begin{array}{l}\text { (1) } 22.6 \mathrm{~g} \\
40 \times 30 \mathrm{~mm} \\
\text { (2) } 300 \mathrm{mg}\end{array}$ & 咽 頭 痛 & リンパ腫 & $\begin{array}{l}\text { 橉酸カルシウム } \\
\text { コレステロール } \\
\text { 蛋白 質 }\end{array}$ & 自然排出 \\
\hline 知念 & 33歳 & 女 & $\begin{array}{c}\text { (1) } 0.9 \mathrm{~g} \\
21 \times 16 \times 13 \mathrm{~mm} \\
\text { (2) } 0.72 \mathrm{~g} \\
14 \times 11 \times 12 \mathrm{~mm}\end{array}$ & 咽 頭 痛 & 扁 桃結石 & $\begin{array}{l}\text { 燐酸カルシウム } \\
\text { 炭酸カルシウム } \\
\text { 蛋 白 質 }\end{array}$ & 両側扁桃摘出 \\
\hline 清 & 14歳 & 女 & $\begin{array}{c}4.4 \mathrm{~g} \\
15 \times 15 \times 12 \mathrm{~mm}\end{array}$ & 扁桃白色化 & 扁 桃 結 石 & $\begin{array}{l}\text { 燐酸カルシウム } \\
\text { 炭酸カルシウム } \\
\text { 蛋白質 }\end{array}$ & 核出術 \\
\hline 吉尾 & & & $\begin{array}{c}2.7 \mathrm{~g} \\
15 \times 12 \times 11 \mathrm{~mm}\end{array}$ & 咽 頭 痛 & & $\begin{array}{l}\text { 燐酸カルシウム } \\
\text { 燐酸マグネシウム } \\
\text { アンモ }\end{array}$ & 両側扁桃摘出 \\
\hline 真鍋 & 49歳 & 男 & $10 \times 11 \times 12 \mathrm{~mm}$ & 咽 頭 痛 & 扁桃周团膿瘍 & 燐酸カルシウム & 両側扁桃摘出 \\
\hline Westmore & 63歳 & 男 & $15 \times 15 \times 13 \mathrm{~mm}$ & 扁桃真菌塊 & 扁桃真菌症 & & 剖検時発見 \\
\hline 自験例 & 26歳 & 男 & $\begin{array}{c}8.5 \mathrm{~g} \\
30 \times 26 \times 16 \mathrm{~mm}\end{array}$ & 咽 頭 痛 & 扁桃周囲膿瘍 & 燐酸カルシウム & 両側扁桃摘出 \\
\hline
\end{tabular}




\section{I ) 症候学的検討}

年代別には，最年少は清ら 22 の14歳の女性で あり，最年長は Hiranandani ${ }^{3}$ の65歳女性であ った．平均年龄36.9歳であった．田村ら4)は青 ・壮年期, 特に40歳代に多い様であると述べて いる. 性差は，男女比は14：6 (70\%：30\%), 不明 1 例で男性に多かった。罹患側は，左側 13 例，右側 7 例，不明 1 例であり，左右差は特 に認めなかった。これらの報告例はすべて片側 であった，症状は，咽頭痛を訴えたものが10例 と多く，次に燕下痛，扁桃肥大が共に 3 例であ った，扁桃白色化を主訴とした者が 2 例で，他 は顎関節痛，咽頭狭窄感，無症状で扁桃に真菌 塊がはまり込んでいたものが各 1 例ずつであっ た. 疼痛を訴えるものが多かったが，扁桃結石 に特有の疼痛はなかった. 初診時に扁桃結石と 診断されたものが 7 例之最も多く，次に扁桃周 囲膿痬が 5 例であった。 3 例は慢性扁桃炎と診 断され，急性扁桃炎，リンパ腫，扁桃悪性腫瘍， 異所性唾液腺腫瘍，vincent angina，扁桃真菌症 が各 1 例ずっであった，九谷 ${ }^{5)}$, Gapany-Gapanavicius $^{6)}$ ， 真鍋 ${ }^{7)}$ の例では扁桃周囲膿瘍を疑 い，膿瘍切開時に結石が偶然に発見されている.

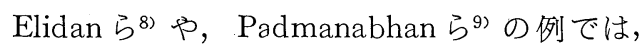
扁桃および軟口蓋の腫脹を認め，腫瘍を疑って 生検したところ結石が発見された。また，文献 上，唾石，胆石，腎結石などの他の結石症との 合併は認めなかった。形状は表面は陥凹し，顆 粒状，色は灰黄色で，円形，卵円形のあのが多 かった．本邦で最も大きいものは山脇らゆの65 $\times 15 \mathrm{~mm}$ であり，海外では Padmanabhan ら の $40 \times 30 \mathrm{~mm}$ の報告がある. 重量に関しては山 脇ら ${ }^{1)}$ の報告例が本邦では最大で $8.5 \mathrm{~g}$ ，本症 例の $8.5 \mathrm{~g}$ は乙れに匹敵するあのと思われる. 次いで, 内藤ら ${ }^{10}$ の $6.6 \mathrm{~g}$ となっている. 海外 においては更に重い報告例が存在し Hiranandani $^{3)}$ の $42 \mathrm{~g}$, Shrimali ら ${ }^{11)} 32 \mathrm{~g}$ 等が見ら れる. 個数に関しては清ら ${ }^{2)}$, 知念ら ${ }^{12)}$ の報告 例では計 4 個であった。計 2 個の報告例は 2 例 で，他の報告例は全て 1 個であった。
成分分析が行われたものが18例であった。う ち16例に燐酸カルシウムが認められ，8例に炭 酸カルシウム，5例に蛋白質が含まれていた。

II）結石の成因について

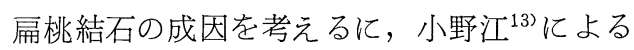
病理学的結石形成理論では，結石形成には， 1）結石の成分となる物質が過䛢に分泌または 排泄されるとと，2）濃縮されるとと，3）液 成分の変化，4）中核および骨組みとなる有機 物質の増量などの要因がある. そして, 結石形 成は脱落上皮, 粘液, 細菌塊, 好中球塊, フィ ブリンなどの有機固形物質が結晶中核となり, 骨組みとなって，その上に無機物質が析出して 行くあので，炎症などによりこれらの有機物質 が増量することが，結石形成を促進すると述べ ている．藤原ら ${ }^{14)}$ の報告例では本症例と同様に 扁桃結石の再発があり, 扁桃摘出の組織像であ 慢性扁桃炎の像を認めた。乙のように扁桃摘出 の病理組織像で扁桃炎の像を認めたものや慢性 扁桃炎や扁桃周囲膿瘍の既往を有する屯のは21 例中 20 例 $(95 \%)$ と大多数を占めていた。 これら より，扁桃結石形成は炎症と深い関連性を有す るものと推察される。唾石, 胆石, 腎結石など の結石症との関連性がないととからす，全身的 な因子よりあ局所因子が大きい要素を占めてい るものと推察された。

発生部位としては，文献的に上局桃窩 5 例, 扁桃被膜之上咽頭収縮笳間 3 例, 扁桃実質 2 例, 上扁桃下部，扁桃上部，扁桃内側面，扁桃表面， 扁桃窩，扁桃洞床，扁桃の上極から下極との記 載が 1 例ずつみられた。また，堀内 ${ }^{15)}$ も，過去 の文献と同様に扁桃上窩が好発部位であろうと 推察している. このように好発部位は上扁桃窩, 扁桃上部と見られる．解剖学的に上扁桃陰窩は 他の陰窩に比べて大きく，深く被膜近くまで達 するという特徵と関連があると推察された。す なわち，同部位に分泌物はうっ滞，貯留，濃縮 され易く結石形成の発症部位となり，乙とから さらに結石が増大，進展し，上扁桃窩に結石が 認められたあのと推察された。 また，小児に扁 
桃結石が少ない理由として, 成人に比べ陰窩の 閉塞，瘢痕が少ないことや陰窩の分岐が少なく 深部まで至らず，結石の骨組みとなる物質がう つ滞, 貯留, 濃縮されにくいためと考えられた. 武田 ${ }^{16)}$ ( 扁桃上窩深部の炎症は容易に被膜に通 じ，扁桃周囲に波及するあのであると述べてい る。さらに，宮口ら ${ }^{17}$ は扁桃炎が，扁桃被膜を 破ると粗な結合組織を越えて上咽頭収縮筋方向 に一気に波及すると言っている。唾液の成分は， ナトリウム, カリウム, 塩素, 重炭酸ソーダ, 燐酸ソーダ, 炭酸カルシウム, 燐酸カルシウム, ロダンカリを含んでいる ${ }^{18)}$ とれらを放置する と二酸化炭素を放出しアルカリ性となりこの時 に，燐酸カルシウムが沈澱する ${ }^{19)}$.

ここで，現在までに報告された扁桃結石の成 因に関する考察をみると，吉田 ${ }^{20)}$ ，内藤ら ${ }^{10)}$ ， Elidan $5^{8)}$ は, 慢性扁桃炎の存在下に剝離した 上皮, 白血球, 細菌塊が核になり, その上に石 灰沈着が生じ結石が形成されるとしている。 ま た，Gapany-Gapanavicius ${ }^{6)}$ はそれに加えて結 石の形成は口内菌叢, 菌類より促進されるとし ている．Hiranandani ${ }^{33}$ は，放線菌が骨組みと なり，その上に石灰が沈着し結石が形成された あのと推察している。扁桃炎の既往を有さなか ったWestomore ら ${ }^{21)} の$ 報告例は，扁桃疾患の既 往がなく，耳鼻咽喉頭領域には無症状で，全身 検索時に口蓋扁桃に真菌塊がはまり込み, 剖検 時にそれが扁桃結石であると確認された，彼ら

は，肺にも真菌による呼吸器感染症があり結石 はこれに起因するものと推察している.

以上より，扁桃結石の成因を考察すると，ま ず細菌性，真菌性など，慢性扁桃炎が基礎にあ り，ついで陰窩内容の扁桃栓，つまり，脱落上 皮, 粘液, 細菌塊, 好中球, フィブリンが増量 し，上扁桃陰窩にうっ滞，貯留が生じる。また， 慢性炎症の反復で陰窩末端の拡張と開口部の狭 窄が生じ，上記の物質が濃縮され，核，骨組み となり石灰化が進行するために必要な環境が作 られるものと考えられた。さらに，次第に唾液 の塩類が沈着し結石が形成されるものと推察さ
れた．徐々に大きくなった結石は周囲の扁桃組 織に機械的刺激を加え, 周囲組織の炎症を助長 し結石形成が促進すると言う, いわゆる悪循環 の関係になったあのと推察された。

本症例では, やがて, 増大した扁桃結石は扁 桃被膜之上咽頭収縮筋間の疎性結合組織に進展 し，あたかも扁桃周囲膿瘍の様な所見を呈した あのと推察される.

III）診断について

吉田 ${ }^{20)}$ ，松井ら ${ }^{22)}$ は，触診や陰窩のゾンデ診 の必要性を述べている， 清ら ${ }^{2)}$ は結石が口腔に 露出しているか，埋没して見えない状態かを比 較し埋没例が70\%を占めていたと報告している. また，報告例のうち 6 例は頭部レントゲン写真 上で結石像を認め診断に有用であると推察され た。扁桃炎や扁桃周囲膿瘍の反復罹患, 治療遷 延，一側の扁桃腫大，白色の苔被を認める慢性 扁桃炎の場合は触診を欠かさず，一度ゾンデに て陰窩を探るべきと思われ，乙の際に頭部レン トゲン写真も撮影すべきであると推論した。

\section{IV）治療法}

扁桃結石の治療法は，扁桃結石だけの核出術， 罹患側の口蓋扁桃摘出術, 健側も含む両側口蓋 扁桃摘出術の 3 通りがある。治療について報告 例を検討すると，結石だけの核出術を施行した あの 9 例であった。罹患側口蓋扁桃摘出術を施 行したもの 3 例で, 両側口蓋扁桃摘出術を施行 したもの 7 例 (両側遺残扁桃摘出術 1 例を含む) であった．自然排出し，無処置の症例，剖検時 に発見された症例各 1 例ずつであった，乙てで

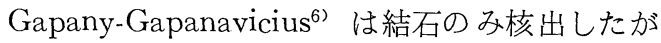
慢性扁桃炎の再発のため 6 年後に両側扁桃摘出 術を施行している. 真鍋 ${ }^{7}$ は Ciari 氏切開後に 結石が自然排出し，14日後に両側扁桃摘出術を している。また，Swain ${ }^{23)} の$ 報告例では同側に 4 回屯再発している.

真鍋7は，(1)扁桃結石だけの核出術は扁桃結 石の再発があるとと，(2)一側の口蓋扁桃の炎症 は対側の口蓋扁桃へも影響を及ぼすとと，(3)美 容的にも口蓋扁桃摘出術は口腔内加ら行えるこ 
と，(4)手術中の危険も比較的少ない，などより 扁桃結石では，両側扁桃摘出術が最も望ましい と述べている.

Pruet ら ${ }^{24)}$ は，結石の外科的摘出が望ましい と述べ，慢性扁桃炎の既往がないものは局所麻 酔下にて核出術の適応となり，慢性扁桃炎の既 往を有する患者では扁桃摘出が望ましいと述べ ている，扁桃結石の成因上，慢性扁桃炎がその 基礎となっていると推察されるととや，核出術 のみでは結石，扁桃炎の再発があることにより 扁桃結石の治療法は両側扁桃摘出術が最も望ま しいと推論した。

\section{結語}

26歳の男性に認められた扁桃周囲膿瘍の症状, 所見を呈した扁桃結石について報告した。結石 は鳩笛状を呈し, 乾燥重量 $8.5 \mathrm{~g}$ であり, 本邦 における過去の扁桃結石の最大重量例に匹敵す るあのとみられた，本症例には両側扁桃摘出術 を施行した．結石の成因ならびに治療法につい て若干の文献的考察を加えて報告した。

本論文の要旨は，第52回耳鼻咽喉科臨床学会にてロ 演した。

\section{参考文献}

1）山脇吉次，岡野善吉：口蓋扁桃結石の症例とその 成因的考察. 耳鼻臨床 $47: 184 \sim 186 ， 1955$.

2) 清恵理子, 三谷芳恵, 上原真由美, 他 : 扁桃結石 の一症例. 日扁桃誌 $25 ： 29 \sim 34,1986$.

3) Hiranandani LH : A giant tonsillolith. J Laryngol Otol 81 : 819 822, 1967.

4) 田村浩通, 佐藤朋也, 森 達吉, 他 : 扁桃結石に 就いて. 広大医誌 $10: 303 \sim 305,1962$.

5 ) 九谷康哉：扁桃腺結石 (学会抄録). 耳鼻臨床 29 : 687 688, 1935.

6) Gapany-Gapanavicius B : Peritonsillar abscess causeed by a large tonsillolith. Ear Nose Throat J $55: 343 \sim 345,1976$.

7 ）真鍋幸二 : 扁桃結石の一例. 耳展 $76: 817 \sim 820$, 1988.

8) Elidan J, Brama I and Gay I : A large tonsillolith simulating tumor. Ear Nose Throat J 59 : 296 297, 1980.
9) Padmanabhan TK, Dutt GSC, Vasudevan DM, et al : Giant tonsillolith simulating tumor of the tonsil; a case report. Indian J Cancer 21:90 91, 1984.

10）内藤 儶，蛙沼 進：巨大な扁桃結石の一症例. 耳鼻臨床 $49 ： 111 \sim 112 ， 1956$.

11) Shrimali $R$ and Bhatia $P L: A$ giant radioopaque tonsillolith. J Indian Med Assoc 58 : 174 175, 1972.

12）知念信雄, 岡本 健, 吉田昭夫 : 扁桃結石の一例. 日耳鼻 $88 ： 370 \sim 371 ， 1985$.

13）小野江為則 : 結石形成. 新病理学総論（武田勝男 編)．76頁，南山堂，東京，1972。

14）藤原文明, 朴沢二郎, 片桐主一, 他：鳩卵大扁桃 結石の一例. 耳鼻臨床 $76: 2917 \sim 2922,1983$.

15）堀内純一: 扁桃結石について。 耳鼻臨床 $37: 14$ $\sim 17,1942$.

16）武田一雄：扁桃周囲炎. 扁桃周团膿瘍. 現代の耳 鼻咽喉科学(檜 学編).578頁, 金原出版, 東京, 1983.

17）宮口 衛, 酒井俊一: 扁桃周囲膿瘍とその再発. JOHNS $5: 1625,1989$.

18）小野尊睦，吉武一貞：唾液の成分，性状. 口腔外 科学. 20～21頁，金芳堂，京都，1987.

19）真島英信：消化および吸収. 生理学. 419頁, 文 光堂, 東京, 1984

20）吉田二郎：扁桃結石症例. 耳鼻臨床 $43 ： 268 \sim$ 269, 1950.

21) Westomore B and Hupp J : Tonsillolith. Oral Sugl $65: 783,1988$.

22）松井健次郎，長谷川栄一：異物を核とせる層状の 扁桃結石の一例. 耳喉 $27: 39 \sim 41,1955$.

23) Swain $H:$ Recurrent calculus of the tonsil ; report of a case. Ann Otol Rhinol Laryngol 29 : 73 78, 1920.

24) Pruet CW and Duplan DA : Tonsil concretions and tonsillolith. Otolaryngol Clin North Am 20 : 305 309, 1987.

$\left(\begin{array}{l}\text { 原稿受付 : 平成 } 2 \text { 年 } 7 \text { 月 } 30 \text { 日 } \\ \text { 原稿採択 : 平成 } 2 \text { 年 } 9 \text { 月 } 19 \text { 日 } \\ \text { 別刷請求先 }: \text { 木村 寛 } \\ \text { T930-01 富山市杉谷 } 2630 \\ \text { 富山医科薬科大学医学部耳鼻咽喉科学教室 }\end{array}\right)$

